\title{
o mercado e o mercado interno no brasil: conceito e história
}

João Antonio de Paula

Professor do CEDEPLAR/FACE/UFMG

\section{RESUMO}

Este texto busca discutir três questões básicas: 1. a natureza e o conceito de mercado no âmbito das ciências sociais; 2 . a centralidade do conceito de mercado interno na gênese e na dinâmica do capitalismo, tal como foi formulado por Marx e certa tradição marxista; 3. os traços essenciais do processo de constituição do mercado interno capitalista no Brasil.

Palavras-chave: mercado interno, capitalismo, Brasil.

\begin{abstract}
This article discusses three basic problems: 1. the nature and use of concept of the market in the social sciences; 2 . the centrality of the concept of internai market, as formulated by Marx and a certain Marxist tradition for explaining the genesis and the dynamics of capitalism; 3 . the essential features of the process of constitution of the capitalist internal market in Brazil.
\end{abstract}

Key words: internal market, capitalism, Brazil.

"Quando se julga que as noções econômicas nasceram das necessidades de ordem material a serem atendidas, e que os termos que traduzem essas noções só podem ter um sentido material, incorre-se num grave erro.Tudo o que se relaciona com noções econômicas está ligado a representações muito amplas, que colocam em jogo o conjunto das relações humanas ou das relações com as divindades: relações complexas, difíceis, que sempre envolvem as duas partes."

Émile Benueniste

A advertência do grande lingüista na epígrafe acima é particularmente pertinente sobretudo para palavras, que, tendo largo e antigo uso, e tendo atravessado diversas épocas históricas, acabam por induzir a que se as vejam como podendo designar fenômenos diversos, às vezes radicalmente distintos, a partir de um signo único consagrado pelo uso. Este é o caso da palavra mercado. De origem latina, a palavra não existia no grego clássico, que também não se ocupou em criar a matriz da palavra 
trabalho. A ausência de palavras gregas para designar o mercado e o trabalho, se não deve ser absolutizada no sentido de ver nisto a ausência, na Grécia antiga, das realidades que aquelas palavras designam, deve ser considerada expressiva como medida da rarefação da vida econômica na Grécia daquele tempo. Esta mesma Grécia clássica reservaria para a economia um lugar subordinado em sua hierarquia de práticas e saberes. Para Aristóteles, a economia só tinha legitimidade quando submetida a preceitos éticos, quando subordinada ao bem comum. Daí que as relações econômicas, as trocas, devessem satisfazer aos princípios dajustiça distributiva. Tudo isto, na verdade, vem reafirmar a historicidade da Economia e de seu vocabulário, a qual deveria refrear generalizações indevidas, que podem levar a anacronismos.

Desde sua origem, a palavra mercado remete aos sentidos correntes de comércio, negócio,feira, praça de comércio, reunião de comerciantes. Presente na língua portuguesa desde o século XIII, essa palavra terá, até o século XIX, um sentido fortemente marcado pela dimensão espacial. É como local, feira, praça, lugar onde se vendem víveres que a palavra está registrada na quinta edição do Dicionário de Moraes Silva, de 1844. Teriam estado ausentes, até aquela data, certos sentidos que, corriqueiros hoje, remetem à sua dimensão abstrata, virtual, e não se referenciam a espaços específicos da realidade múltipla do mercado no mundo contemporâneo.

Por outro lado, o texto de Benveniste permite que se reconheçam os diversos conteúdos que as palavras vão assumindo em conformidade com os diversos campos em que são apropriadas. No caso da palavra mercado, há pelo menos dois grandes sentidos que se lhe atribuem. Há o uso que dela fazem os economistas e, de outra parte, a apropriação da palavra decorrente da prática discursiva e da investigação de antropólogos e historiadores. Como dizWalter Neale,"para o economista o mercado é uma instituição com leis próprias sobre as quais se constituiu uma sólida estrutura analítica; para o historiador e o antropólogo, o mercado é um lugar de reunião para a troca de produtos, lugar que não tem porque ser a base da teoria econômica que os economistas criaram" (Neale, 1976:405).

É neste sentido que Karl Polányi, e também Mareei Mauss, além de uma série de outros estudiosos, irão identificar diversas relações de troca, que tendo papéis fundamentais na cimentação de determinadas sociedades, realizam-se a partir de motivações que nada têm em comum com o que presidiria a aparentemente única motivação para a troca, que seria a busca do interesse individual a partir da regra impessoal da 
concorrência, e que definiria, por meio de preços, a equivalência das trocas. Polányi, Malinowsky, Mauss, Lévi-Strauss, Chayanov, Pierre Clastres, Marshall Sahlins, Lawrence Krader, Eric Wolf, entre outros, mostraram a existência de diversas motivações não-mercantis da troca: reciprocidade, dádiva, parentesco, redistribuição, vizinhança etc. Esta é a base da crítica de Polányi quanto à disseminada presença, entre os economistas, de uma "obsoleta mentalidade mercantil" (Polányi, 1978), a qual consiste na dificuldade de se entender que o mercado e a economia podem não ter em todas as sociedades a centralidade que possuem na sociedade capitalista; e que, em certas sociedades, a economia pode estar sob controle, subordinada a regras éticas, culturais, religiosas e políticas que vão além de todo cálculo ou interesse individual.

A grande questão aqui é saber se a troca é ubíqua, se tem a espessura das limitações humanas e naturais, que obrigam à divisão do trabalho, ou se nem toda troca é mercantil e nem todo local de troca configura um mercado. Além disso, nem todo mercado é mercado capitalista. Distinguir estas questões significa tanto considerar a apropriação que a história e a antropologia fazem da palavra mercado, como destacar o específico desta palavra, tal como é usada pelos economistas e pela crítica da Economia Política.

Neste artigo vai se, num primeiro momento, apresentar o conceito de mercado. Num segundo passo irá se discutir a importância decisiva do mercado interno na gênese e dinâmica das economias capitalistas. Por último, a parte final do texto deverá considerar a especificidade do processo de constituição do mercado interno no Brasil.

No centro do argumento que se procura desenvolver aqui há uma tensão. De um lado, temos o reconhecimento da exigência definidora do próprio fazer historiográfico, que é a recusa do anacronismo. Johan Huizinga vai apresentar assim a questão: "A história se distingue destas outras formas do espírito" (filosofia, literatura, direito, ciências naturais) "em que se projeta sobre o passado e somente sobre o passado. Pretende compreender o mundo no passado e através dele." (Huizinga, 1980:92). Ou seja, a história legitima-se como discurso rigoroso apenas quando é capaz de iluminar o passado a partir dos elementos que este mesmo passado contém. Daí o pecado de se projetar para o passado conceitos, mentalidades, vocabulário, realidades que não estavam, e nem poderiam estar lá, porque são resultados do contemporâneo. Se esta é exigência absoluta e incontornável como procedimento e perspectiva, admita-se a força oposta decorrente da tese de Croce,de que só existe uma história, a história contemporânea. Eis uma tensão que tem foro de aporia, entre 
buscar fugir do anacronismo, que é inaceitável na historiografia, e, ao mesmo, reconhecer o inafastável do comprometimento decorrente de nossa condição de sujeitos contemporâneos — isto é, de sujeitos que não podem evitar serem o que são, e projetarem em tudo o que escolhem vertanto o seu tempo como os seus condicionamentos. Se isto não nos desonera de buscar evitar o anacronismo, que seja ao menos o reconhecimento da existência de uma tensão permanente e desafiante no corpo da historiografia.

\section{O Conceito de Mercado}

No segundo tomo de sua trilogia - Civilização Material, Economia $e$ Capitalismo - Fernand Braudel diz que os mercados são antigos, estando presentes desde a Antigüidade, e que existiram em todo o mundo - na Grécia e em Roma, no Egito, no México, na Europa e na África. E, mais ainda, ele passa a definir o mercado e apresentar suas características: "é preciso falar da economia de mercado desde que há flutuação e uníssono de preços entre mercados de uma mesma zona." (...) "Desde a antigüidade, os preços flutuaram; no século XIII, flutuam já conjuntamente através da Europa..." (Braudel, 1985:203).

Braudel quer afastar incompreensões, dizendo que "sociólogos e economistas de ontem, antropólogos de hoje, habituaram-nos infelizmente à ignorância quase perfeita da história" (Braudel, loc. cit.). Nessa tarefa de fazer valer o conhecimento histórico, Braudel quase nos leva a pensar que o mercado é uma realidade ahistórica. Ao vê-lo em todo tempo e lugar, parece haver quase um apagamento das especificidades históricas do mercado, confundido e igualado a toda e qualquer troca material expressa mediante preços. Mas, em tempo, Braudel nos lembra que,"de todos estes mercados difusos, o mais importante segundo a lógica deste livro, é o mercado de trabalho" (Braudel, 1985:40). Ao afirmar isto, Braudel se abre para reconhecer algo que é decisivo para a compreensão do mercado como realidade histórica, e do mercado capitalista em particular - a radical transformação histórica que ele significa, ao irromper como violência e coerção.

Ellen Meiksins Wood, a partir das idéias de Robert Brenner, fez um balanço das teses clássicas sobre a gênese do capitalismo nas quais aponta uma problemática continuidade — com poucas exceções, em que se destaca Polányi - entre autores, como Dobb e Sweezy, por exemplo, que adeptos de perspectivas divergentes sobre o assunto, têm a unificálos uma mesma adesão a certo modelo - que ela vai chamar de mercantil 
- cujo sentido básico é ver em tudo que antecedeu ao capitalismo uma longa preparação para a sua emergência. Perspectiva claramente ahistórica e fortemente anacrônica, este modelo mercantil entenderia a história européia como uma superação dos obstáculos que ao longo do tempo impediram a plena vigência do capitalismo. O essencial da tese de Ellen Wood é afirmar as diferenças decisivas que existem entre a auferição de lucro comercial e a acumulação de capital; o mercado como oportunidade e o mercado como imperativo e coerção; entre os processos transitórios de desenvolvimento tecnológico e o impulso capitalista específico para aumentar a produtividade do trabalho. Ou ainda, mais especificamente, afirmar que

"o mercado capitalista, como forma social específica,perde-se quando a transição das sociedades pré-capitalistas para as sociedades capitalistas é apresentada como uma extensão ou maturação mais ou menos natural, ainda que muitas vezes distorcida, de formas sociais já existentes: como uma transformação mais quantitativa que qualitativa." (Wood, 2001:17).

Para Ellen Wood, apoiada em Robert Brenner, e afinal a partir de Marx, o que caracteriza o capitalismo é a imposição do mercado, não como oportunidade ou escolha, mas como compulsão — no sentido de que

"a vida material e a reprodução no capitalismo são universalmente medidas pelo mercado, de forma que, de um modo ou de outro, todos os indivíduos têm que entrar nas relações do mercado para ter acesso aos meios de subsistência; e segundo, os ditames do mercado capitalista - seus imperativos de competição, acumulação, maximização de lucros e crescente produtividade do trabalho - regem não apenas todas as transações econômicas, mas as relações sociais em geral." (Wood, 2001:16).

Para Marx, como para Polányi, a gênese do mercado capitalista não é simples generalização - extensão das trocas, do comércio, da monetização. A imposição do mercado capitalista é uma revolução social. De acordo com Marx:

"A expropriação e a expulsão de uma parte da população rural libera trabalhadores, seus meios de subsistência e seus meios de 
trabalho, em benefício do capitalista industrial; além disso cria o mercado interno. Na realidade, os acontecimentos que transformam os pequenos lavradores em assalariados e seus meios de subsistência e meios de trabalho em elementos materiais do capital, criam ao mesmo tempo para este o mercado interno." (Marx, 1968:1, 865).

Trata-se, pois, de ver na constituição do mercado capitalista processo qualitativamente distinto da existência de relações mercantis, de produção e apropriação de lucros mediante o monopólio do comércio exercido pelos detentores das formas pretéritas do capital, anteriores ao domínio do capital industrial, como o são o capital usurário e o capital mercantil. (Marx, 1968:1, 867).

Para concluir, nem o comércio, nem o dinheiro, nem o mercado são idênticos ao sistema de mercado, isto é, ao mercado auto-regulado. Ou, como dizWalter Neale,

"os mercados auto-regulados são a exceção e não a regra e inclusive só aparecem nos séculos XIX e XX" (...) "os mercados criadores de preços (são) um produto histórico excepcional" (...) "durante boa parte de sua trajetória histórica o homem viveu com mercados de preços fixos, e talvez, com sistemas econômicos que podem ser melhor compreendidos em termos de instituições de reciprocidade e redistribuição cujas características essenciais se definem à margem da teoria econômica ortodoxa e com a ajuda de outras disciplinas mais familiarizadas com as instituições alheias ao mercado." (Neale, 1976:417-420).

No que interessa centralmente este texto, trata-se de buscar entender a relativamente longa trajetória dos mercados no Brasil (desde o início da colonização e a vigência do escambo até a multiplicação e complexificação dos mercados, a partir do final do século XVIII) como processo histórico - isto é, como processo de vivência das diferenças, do que é sempre singular e irrepetível, mesmo quando expressando conteúdos universais. É este o material de que é feita a história, o tecido que se tece a si mesmo pela intercorrência da cor local, pelas variadas maneiras como as sociedades se apropriam e aclimatam as realidades gerais. Assim, a implantação do mercado no Brasil não seguiu qualquer pauta prévia, não reproduziu qualquer padrão anterior, mas foi um processo único.

Dentre as suas singularidades convém referir três, que são marcantes e deixaram conseqüências: 1) a longa permanência no Brasil da fragmentação do mercado interno - apesar do embrião de articulação do 
mercado interno, representado pela economia mineira no século XVIII, a realidade dominante do mercado interno no Brasil, foi, até a segunda metade do século XX pelo menos, a sua falta de integração, a existência de um efetivo arquipélago de relações de trabalho, tecnologias, graus de mercantilização e monetização, estruturas fundiárias regionalmente diferenciadas; 2) o importante papel no desenvolvimento das relações econômicas no Brasil da continuidade de uma política de terras, que, herdada da tradição sesmarial lusitana, prolongou-se no latifúndio e no bloqueio ao acesso à terra aos muitos que dela dependem, e que a demandam desde a época colonial até os mais recentes movimentos de luta pela terra; 3 ) a importância da modalidade especificamente brasileira de constituição do mercado de trabalho, marcada pela longuíssima duração da escravidão e pela pesada herança de uma sociedade parasitária e excludente, que tem reiterado historicamente mecanismos de interdição de direitos sociais e de desqualificação da força de trabalho.

Trata-se, enfim, de buscar compreender o processo de constituição do mercado interno brasileiro como processo de modo algum linear ou automático, marcado que foi, e continua sendo, pela presença de variadas formas de mercados não-capitalistas, em que a imposição de um mercado efetivamente capitalista - isto é, de um mercado em que a terra e a força-de-trabalho são mercadorias, em que há a imposição da busca do lucro e da acumulação do capital pelo aumento da produtividade do trabalho - deu-se de forma tal que o capitalismo que aqui se desenvolveu foi assumindo estruturalmente características de atrofia, vulnerabilidade, incompletude e dependência externa, tornando-se um certo tipo de desenvolvimento capitalista.

\section{A Questão do Mercado Interno}

O processo de constituição do capitalismo não se resume ao que é mais imediato e aparente nas relações econômicas.Trata-se da imposição de uma ordem - isto é, da imposição de determinadas relações sócioeconômico-político-culturais que, articuladas, sistêmicas, como se diz hoje, garantem a reprodução dos interesses de uma determinada classe, que, para dominar plenamente, deve, ao lado do monopólio da força da coerção e da riqueza, buscar o consentimento e a legitimação. Daí o importante papel da ideologia e das instituições que a produzem.

Neste sentido, não se veja no que vai dito a seguir uma subestimação dos aspectos político-culturais na gênese e dinâmica do capitalismo, os quais são decisivos para a realização do mais concreto das relações eco- 
nômicas. É o que se vê na análise que Marx faz do papel disciplinadorformador da classe operária, do mercado de trabalho, de instituições como as Workhouses, a "legislação sanguinária contra a vadiagem", etc.

No que se segue buscou-se acompanhar um roteiro de questões centrais na gênese do mercado interno, que, apresentado por Marx em O Capital, foi retomado por Lênin e Emílio Sereni, em suas análises das realidades da Rússia e da Itália respectivamente. Neste roteiro são centrais os seguintes temas: 1) a constituição do mercado de trabalho;2) a constituição do mercado de terras; 3) o grau de articulação-interação do mercado interno verificado pela análise da variância dos preços entre as diversas regiões; 4) o sistema de transporte e comunicações; e 5) a dinâmica demográfica da população economicamente ativa.

Privilegiar estes aspectos não significa ignorar a existência de outros fatores determinantes decisivos na gênese do capitalismo, mas apenas replicar um modo de aproximação da realidade capitalista, que permita comparações expressivas com estudos clássicos sobre o assunto.

Encontra-se na obra de Lênin a seguinte afirmação: "o 'mercado interno'para o capitalismo é criado pelo próprio capitalismo em desenvolvimento, que, ao aprofundar a divisão social do trabalho, divide os produtores diretos em capitalistas e operários. O grau de desenvolvimento do mercado interno é o grau de desenvolvimento do capitalismo no país." (Lênin, 1973:63).Desta frase sublinhe-se que o desenvolvimento do capitalismo se expressa como desenvolvimento do mercado interno, e que este é função da divisão social do trabalho, a qual será tanto maior, quanto mais generalizado for o processo de transformação dos meios de produção em capital constante, e dos meios de subsistência em capital variável. (Lênin, 1973:62).

A análise clássica da pioneira imposição do mercado capitalista foi realizada por Marx em $O$ Capital. Esta obra, que tem um andamento expositivo ao mesmo tempo lógico e genético - com a apresentação do argumento não seguindo a cronologia, mas o acontecer ontológico das categorias - tem ensejado certas leituras, que, contrariando o sentido essencial que aquele autor quis imprimir ao seu texto, acabaram por ver na trajetória da história do desenvolvimento capitalista na Inglaterra, uma espécie de roteiro necessário e intransponível para todos os países.

Esta interpretação, tornada dogma na época stalinista, tanto paralisou a pesquisa histórica, quanto bloqueou resultados que pareciam contrariar o cânone, como no caso da discussão do modo de produção asiático. Ao mesmo tempo, teve importantes e problemáticas conseqüências políticas decorrentes da imposição da famigerada teoria das etapas. Diga- 
se, também, que esta leitura empobrecedora buscou apoio numa passagem do prefácio da primeira edição de $O$ Capital, de 1867, quando Marx, usando expressão latina, diz "De te fabula narratur", e acrescenta que "o país mais desenvolvido não faz mais do que representar a imagem futura dos menos desenvolvidos". E também em outros exemplos e metáforas como "a anatomia do macaco deve ser entendida à luz da anatomia do ser humano" em que há uma reiteração da mesma idéia - visceralmente dialética - de que o desenvolvimento é, sobretudo, explicitação e expressão do que está contido no ser, um desdobramento dos conteúdos e das potencialidades do que está em germe em todo o real, em todo o existente.

Contudo, se esta idéia pode conduzir a interpretações que resultam em anular a história como realização de processos singulares energizados por forças específicas, insista-se que esta não é uma interpretação legítima da perspectiva central de Marx. Seria, de fato, quase um paradoxo, com algo de perverso, que se viesse atribuir a Marx uma visão ahistórica da realidade. Foi Marx, e nenhum outro, que disse que só existiria uma ciência - a ciência da História - e que esta história, no caso central da sociedade humana, teria como fundamento a luta de classes - isto é, a permanente flutuação de sentidos, de correlação de forças, a permanente produção de hegemonias e contestações, de acasos e surpresas.

Neste sentido, tomar como material empírico a história do desenvolvimento do capitalismo na Inglaterra não constitui a imposição de um modelo, mas apenas uma explicitação da modalidade, específica e inimitável, inglesa da imposição da vitória de um dos componentes da larga e difusa época histórica, que se abre com a crise do feudalismo. As teses de Brenner e de Wood já discutidas aqui, dão conta da existência, neste período, de diversas forças, tendências e interesses conflitantes. Ao final, uma destas forças iria prevalecer — os produtores rurais, que, tendo se apresentado, inicialmente como arrendatários, iriam impor um conjunto de transformações nas relações técnicas e sociais na agricultura, cujo resultado final seria a imposição do capitalismo no campo. Foram estes capitalistas agrários, que, vitoriosos no campo, mais tarde iriam impor à cidade, às atividades urbano-industriais, as mesmas regras prevalecentes no capitalismo agrário.

Torna-se decisivo sublinhar aqui que o capitalismo não estava lá, em algum lugar, à espera de nascer, esperando que se lhe retirassem as amarras. O capitalismo era, no contexto do fim do feudalismo, uma das possibilidades do desenvolvimento histórico, e ele não se implantou e generalizou pacífica e integralmente. Neste sentido, a história do desenvolvi- 
mento do capitalismo na Inglaterra não é a história de seu melhor caso, pois isto não existe, já que, em cada local, em cada época, a partir de um conjunto específico de condicionamentos, o capitalismo vai se desenvolver, ou mesmo deixa de nascer, porque sua história está longe de ser uma história natural.Trata-se da história da imposição de uma ordem, de uma lógica, de um conjunto de regras e interesses contra outras ordens, lógicas, regras e interesses.

A partir da análise de Marx do capitalismo na Inglaterra, é possível estabelecer-se um conjunto de mecanismos formativos: a acumulação primitiva, significando a constituição do mercado de terras e de trabalho; a acumulação de riqueza financeira e monetária; um determinado conjunto de políticas - o mercantilismo - comandados por um certo tipo de Estado; uma certa revolução político-social que transfere o poder de Estado para os capitalistas; uma certa revolução das forças produtivas que possibilita o a mento sistemático da produtividade do trabalho.

Na verdade, o que está implícito na análise de Marx é que estes me canismos formativos dizem respeito a todos os processos de constituição do capitalismo. Trata-se de reconhecer que estes mecanismos, indispensáveis a qualquer processo de formação do capitalismo, assumirão aspectos particulares em cada país onde ocorrerem. Assim, para a História, não se trata de buscar em cada país os equivalentes dos processos ingleses de formação do capitalismo, mas de compreender as características específicas que marcariam, em cada país, a constituição do seu mercado interno - o que implica em apreender as modalidades nacionais da constituição dos elementos formativos do capitalismo.

Lênin fez isto no seu Desenvolvimento do Capitalismo na Rússia. Emílio Sereni, em seu Capitalismo e, Mercado Nacional, é um outro exemplo de boa aplicação das teses de Marx sobre a gênese do capitalismo.

Na Itália, o fator específico do processo de constituição do mercado interno viria das vicissitudes do processo da unificação e do Risorgimento italianos, a partir de 1861. Foi Gramsci quem abriu caminho para a análise de Sereni, a partir da sua tese sobre a questão meridional. No centro desta tese está o reconhecimento das importantes conseqüencias decorrentes do desenvolvimento desigual do sul da Itália em relação ao norte. Essa desigualdade, que tem fundas raízes no desenvolvimento histórico italiano, determinou diversas conseqüencias econômicas, políticas e sociais que se expressaram no processo de unificação inconcluso; num processo de modernização desigual e num processo de constituição do mercado interno atrofiado, disto resultando a reiteração da precariedade material do sul da Itália. 
Emílio Sereni trouxe uma considerável contribuição à discussão sobre a constituição do capitalismo, na medida em que propôs uma metodologia para medir o grau de unificação do mercado interno de cada país e, neste sentido, do grau de desenvolvimento do capitalismo através da análise da dispersão dos preços de uma dada mercadoria entre as regiões que compõem um país. Quanto maior for a correlação entre os preços, e menor a dispersão deles, tanto maior será o grau de articulação da economia e tanto mais plenamente constituído estará o capitalismo. A idéia básica aqui é a de que o mercado capitalista pleno só existe quando os preços variam regionalmente apenas em função dos custos de transporte (Sereni, 1980:37). Assim, uma grande dispersão regional dos preços de uma mercadoria é indício da existência de diversas e heterogêneas estruturas produtivas, com diferenciadas relações de trabalho e tecnologias, revelando que, afinal, o modo de produção capitalista ainda não chegou a subordinar toda a economia.

\section{O Caso do Brasil}

No caso do Brasil vai-se procurar discutir a constituição do mercado interno pela análise das imposições do mercado de terras e de trabalho. Ao lado do estabelecimento das condições específicas da constituição dos mercados de terra e trabalho no Brasil, que iria marcar o essencial do mercado interno que aqui se fez - isto é, do desenvolvimento capitalista no País - também teve papel importante neste processo formativo a longa presença de uma efetiva desarticulação entre as diversas regiões brasileiras. Desde o período colonial, constituíram-se economias regionais na América Portuguesa com pequenas, quando existentes, interações entre si. Tal fato se deveu tanto à precariedade dos sistemas de comunicação e transportes, quanto, mais importante, às profundas diferenças estruturais entre essas economias regionais.

Grosso modo, é possível identificar-se quatro grandes economias regionais no período colonial: a economia nordestina, que, se não pode ser resumida à plantation açucareira, tem nesta atividade sua marca decisiva, daí decorrendo a predominância do trabalho escravo e do latifúndio. Ao lado da agroindústria açucareira começou a impor-se, no século XVIII, a produção algodoeira, que chegou a ter surtos expansivos em função de restrições nas exportações do grande produtor, os Estados Unidos, com uma organização de produção e localização espacial distintas das prevalecentes na atividade açucareira, sendo nela comum a utilização de mão-de-obra livre do trabalho familiar. Essa produção 
tampouco iria concorrer por terras com a cana-de-açúcar, já que foi se expandir em áreas do Agreste e do Sertão, deixando as áreas da Mata Atlântica para o cultivo da cana. Ao lado destas duas atividades ainda tiveram importância na economia nordestina: uma pecuária extensiva, baseada em trabalho livre, sob a forma de parceria; a produção de tabaco, sobretudo na Bahia, que exerceu papel importante como moeda de troca no tráfico de escravos; e uma disseminada agricultura de alimentos, que tanto foi desenvolvida pelo trabalho familiar, como fez parte do sistema escravista sob a forma da "brecha camponesa", de que fala Ciro Cardoso, e que resultava da liberação de parte da semana do trabalho do escravo para que pudesse cultivar certo lote de terra e se auto-sustentar.

Uma segunda economia regional característica na América Portuguesa foi a Amazônica, na qual houve mais de um traço distintivo, quando comparada ao resto da Colônia. É que a Amazônia - compreendendo as Capitanias do Grão-Pará, Maranhão, Piauí, Rio Negro, e, em alguns momentos, mesmo o Ceará - teve administração própria, constituindo um Estado separado do Brasil, até 1808, sendo primeiramente, em 1621, chamado Maranhão, depois Grão-Pará e Maranhão em 1751. Reorganizada com formações diferentes, essa região teve uma trajetória singular no contexto colonial-português. Seu traço mais marcante foi a ampla difusão, nas capitanias do Grão-Pará e Rio Negro (criada em 1750), de uma economia de coleta, extrativismo, de exploração das chamadas "drogas do sertão" (madeiras, resinas, fibras, caça e pesca etc.) a partir do trabalho indígena servilizado e controlado por ordens religiosas (jesuítas, franciscanos, mercedários, carmelitas). Com exceção do Maranhão, que teve uma forte presença da plantation produtora de algodão, nas outras Capitanias foi pequena a presença do trabalho escravo, como também seria ali peculiar a questão fundiária. Numa economia que depende dos frutos da floresta, o que importa, de fato, é a integridade da floresta - seus recursos faunísticos e florísticos. Disso decorre uma menor relevância da terra como suporte da produção agrícola, donde a considerável preservação da floresta até hoje.

No extremo sul da América Portuguesa, iria desenvolver-se uma outra economia regional específica. Seus traços marcantes foram: 1) sua especialização numa produção voltada para o mercado interno; 2) a pequena participação do trabalho escravo, que se concentrou sobretudo na atividade pecuária no sul da Capitania de Rio Grande de São Pedro; 3) a ampla difusão de uma agricultura familiar, em pequenas e médias propriedades, resultando daí uma estrutura fundiária bem mais desconcentrada que a prevalente no resto do Brasil. 
Finalmente, uma quarta economia característica na América Portuguesa foi a da Capitania das Minas Gerais. Centrada na mineração do ouro e dos diamantes com base no trabalho escravo, teve uma estrutura produtiva diversificada - que contemplou atividades manufatureiras e agro-pecuárias - considerável para a época e local, além de um nível de urbanização, e outros traços de uma certa modernidade, que a singularizaram no contexto colonial. Contudo, todas estas características potencializadoras de dinamismo e crescimento da economia mineira, sua articulação com as economias nordestina e sulina, tudo isto, afinal, não iria resultar em efetiva constituição do mercado interno, na medida mesmo em que isto não implicou mudanças estruturais, conservando-se cada economia regional intocada no essencial de suas estruturas sócio-econômicas.

Esse quadro, prevalecente no período colonial, não seria alterado, no fundamental, na época imperial. Vários autores, Celso Furtado enfaticamente, iriam mostrar que não houve alteração estrutural de monta com a Independência do Brasil, que, no essencial, manteve a mesma dependência externa, a escravidão, a desarticulação das economias regionais, as quais, no essencial, tampouco não experimentaram mudanças estruturais. É neste quadro que se deve buscar entender a emergência dos mercados de terra e trabalho no Brasil.

Uma forte evidência da inexistência de um mercado interno articulado no Brasil do século XIX foi apresentada por Evaldo Cabral de Melo, ao mostrar a diferença entre as taxas dejuros praticados na economia cafeeira (10 a $12 \%$ a.a.) vis-à-vis as prevalecentes na economia nordestina, que oscilavam entre 18 e $24 \%$ (Melo, 1984).

\section{O mercado de terras}

Entre as instituições centrais da ordem capitalista destacam-se o mercado de terras e o do trabalho. Se o dinheiro é o ponto de partida histórico e genético da acumulação capitalista, como disse Marx, a monopolização da terra e dos demais meios de produção, por uma classe, e a proletarização de uma outra classe, que assim é obrigada a vender a sua força de trabalho como forma básica de sobrevivência, são os processos constitutivos da chamada acumulação primitiva do capital.

No caso do Brasil, este foi um longo processo, que se prolongou do século XVI ao XX, com importantes diferenças regionais, sobretudo no que diz respeito aos ritmos da proletarização e de mercantilizaçãomonopolização da terra. 
A origem do regime de terras no Brasil remonta à tradição medieval portuguesa. A sesmaria, instituída em 1375, por D. Fernando, rei de Portugal, foi a forma de distribuição e ocupação das terras no Brasil até 1850. Entre seus objetivos básicos, a sesmaria incluía o cultivo das terras ociosas para aumentar a riqueza do Reino. A lei das sesmarias, de 26 de junho de 1375, foi sucessivamente incorporada às Ordenações Afonsinas, Manoelinas e Filipinas, definindo neste sentido a política de terras do reino português até o século XIX (Porto, 1965).

Derivada da palavra latina seximum, que significa a sexta parte, a palavra sesmaria acabou assumindo característica genérica de terras doadas, casas ou pardieiros, com vistas ao cultivo. No Brasil o regime sesmarial implantou-se ao mesmo tempo que as Capitanias Hereditárias, definindo um padrão que iria marcar definitivamente a estrutura fundiária brasileira como a do latifúndio. Distribuídas segundo um módulo mínimo de uma légua quadrada, ou $6.600 \mathrm{~m}^{2}$, a estrutura sesmarial não seria ho mogênea, contemplando desde verdadeiros "impérios territoriais" - como a sesmaria da Casa Garcia d'Àvila, que margeava o Rio São Francisco - até sesmarias menores de apenas uma légua quadrada.

Na verdade, o motivo básico da lei de sesmarias era a busca do cultivo da terra. Uma sesmaria improdutiva deveria ser repartida de tal forma que toda ela produzisse riquezas. Contudo, este princípio parece nunca ter sido observado, resultando daí a consolidação do latifúndio. Era explícito neste sentido o Regimento do Governador Geral Tomé de Souza, de 1548, que mandava distribuir as terras em sesmarias mas condicionava esta distribuição aos que possuíssem cabedal suficiente para construir casas-fortes, o que significava excluir do universo das sesmarias os pobres. Este traço da terra como monopólio dos potentados locais estaria na base de uma estrutura fundiária concentrada, ponto de partida para a conformação do poder oligárquico, do fenômeno fundamental de nossa vida política e cultural que foi o coronelismo.

Não se deve ver o regime sesmarial, desenvolvido no Brasil como uniforme em todas as suas regiões. Na verdade, foi sobretudo no contexto da grande empresa agro-manufatureira exportadora colonial que a questão da terra teve centralidade. Neste particular, a questão da terra, a posse de grandes áreas, a importância do latifúndio, teve peso menor na economia extrativista das drogas do sertão da Amazônia, ou mesmo na economia mineratória. O latifúndio era, como foi observado por vários estudiosos, um dos pilares de uma tríade que incluía a monocultura e o trabalho escravo. Essa estrutura, designada genericamente como plantation, marcou a economia açucareira nordestina, definindo os traços bá- 
sicos de uma trajetória sócio-econômica que secularmente iria reproduzir um padrão de concentração da terra, da renda e do poder.

Não se veja nisto, contudo, um processo homogêneo ou linear, pois mesmo a estrutura clássica da plantation admitia variantes e diferenças. Veja-se o seguinte trecho de Roberto Smith:

"A distribuição de terras através de sesmarias, na área canavieira do Nordeste como um todo, mostrava, em meados do século XVI, a existência de algumas sesmarias contendo grandes áreas, porém boa parte delas era de tamanho menor. Stuart Schwartz assinala que na Bahia essas sesmarias mediam usualmente menos de duas léguas quadradas. Célia Freire A Fonseca, em uma pesquisa de 1.141 sesmarias na Paraíba, mostra que $87,5 \%$ delas eram menores de 4 léguas quadradas" (Smith, 1990:297).

Stuart Schwartz em seu livro Segredos Internos (1988), havia mostrado o equívoco de se ver a realidade da economia nordestina como resumida à tríade latifúndio-escravidão-monocultura. Neste seu livro, sob vários aspectos fundamental, figura a reconstituição de uma realidade sócio-econômica menos esquemática, com a revelação de estruturas intermediárias entre os grandes senhores e os escravos, e a presença de uma considerável diversidade no referente ao tamanho da propriedade, às atividades produtivas, ocupações profissionais, condição social etc. Este é também o sentido básico das teses de Ciro Flamarion Cardoso sobre a existência de uma "brecha camponesa" nos interstícios da economia escravista no Brasil (Cardoso, 1982)

O que se deseja evitar aqui é uma generalização incompreensiva que queira ver homogeneidade e uniformidade num quadro histórico e espacialmente marcado pela diversidade. Por exemplo: se o latifúndio e a escravidão foram fundamentais na economia pecuária do couro, do charque e do gado em pé, na região de Pelotas durante o período colonial, a agricultura de alimentos do mesmo Rio Grande de São Pedro, sobretudo a desenvolvida pela colonização alemã, a partir de 1825 , da região da Serra Gaúcha, teria um padrão de distribuição da terra e uma forma de organização do trabalho marcados pela desconcentração fundiária e pelo trabalho familiar. Não por acaso, nestas regiões, no Rio Grande do Sul e em Santa Catarina, onde não prevaleceu o latifúndio e tanto a terra como a renda foram mais desconcentradas, são as que têm os melhores indicadores de qualidade de vida no Brasil contemporâneo. 
Se é verdade que, apesar das diferenças regionais, a política de terras no Brasil consagrou o latifúndio, também é verdade que este processo não foi isento de ambigüidades. Basicamente pode-se depreender da política de terras praticada no Brasil que as tentativas da Coroa de impedir a concentração fundiária foram frustradas. Como diz Emília Viotti da Costa:

"Era evidente nessas proibições a intenção da Coroa de evitar concentrar a terra nas mãos de poucos, para impedir a criação na colônia de uma nova ordem feudal. As expectativas da Coroa, entretanto, foram frustradas. Os proprietários de engenho tenderam a acumular terra, não somente para assegurar o fornecimento de cana para seus engenhos, mas também porque a propriedade da terra concedia prestígio social" (Costa, s.d.:143-144).

A questão fundiária no Brasil de nenhum modo foi pacífica para os governantes portugueses. Em 1795, houve uma tentativa de modificar a política de terras, abolindo o regime das sesmarias. O Alvará de 5 de outubro de 1795 dizia: "Que sendo-me presentes em consulta do Conselho Ultramarino os abusos e irregularidades, e desordens, que têm grassado, estão e vão grassando em todo o Estado do Brasil, sobre o melindroso objeto de suas sesmarias..." (Smith, 1990:285). A suspensão desse Alvará, ainda que inaplicado, reflete a existência de uma tensão crescente entre interesses que vão se diversificando. Não é possível uma identificação unívoca destes interesses. Não se tratava de uma clivagem entre interesses locais e interesses metropolitanos, ou entre interesses nativistas e interesses coloniais.Tanto o Alvará frustrado, quanto o Decreto que o bloqueou faziam parte de um contexto marcado pela explicitação de "projetos" alternativos para o Brasil. Quem talvez tenha melhor sintetizado estas questões, naquele momento, foi José Bonifácio.

Em diversos momentos e a propósito de questões essenciais para a vida econômica e social do Brasil, José Bonifácio teria um papel de destaque (Silva, 1964). Ele foi responsável pelo primeiro projeto sistemático de construção de uma nova ordem sócio-econômica para o Brasil. O primeiro ponto deste projeto era a denúncia das sesmarias como incompatíveis com o desenvolvimento da agricultura no Brasil. Sua proposta de 1821 estabelecia que o acesso à terra no Brasil a partir daí dar-se-ia apenas mediante a compra, e que os lotes não poderiam exceder a meia légua quadrada (Smith, 1990:286). No conjunto o projeto incluía ainda o fim do tráfico de escravos, a abolição progressiva da 
escravidão, o desenvolvimento de atividades agrícolas baseadas no trabalho de colonos (Smith, 1990:288).

Embora houvesse, desde 1822, uma clara intenção de pôr fim às velhas instituições das sesmarias, foi só em 1850, com a Lei de Terras, de 18 de outubro, que iria haver uma efetiva mudança da política fundiária no Brasil. A Lei de Terras de 1850 foi coetânea de dois outros instrumentos legais, o Código Comercial e a Lei Eusébio de Queiroz, que aboliu o tráfico de escravos. As três significaram, em conjunto, a emergência no Brasil do processo de constituição de um mercado especificamente capitalista. Este foi o início do processo de transformação da terra e da força de trabalho em mercadorias.

EmíliaViotti da Costa resumiu o essencial da Lei de Terras em quatro pontos básicos: 1) o acesso às terras públicas, a partir daí, dar-se-ia apenas pela compra; 2) o tamanho das posses, terras apropriadas mediante ocupação, foi limitado ao tamanho da maior doação feita no distrito em que se localizavam; 3) o produto da venda das terras seria usado para financiar a vinda de imigrantes para o Brasil e 4) a criação da Repartição Geral das Terras Públicas para administrar o processo e promover a migração (Costa, s.d:140 e 141).

Neste processo é preciso observar que, apesar de formalmente abolidas as sesmarias, a constituição de latifúndios, na verdade, acelerou-se entre 1822 e 1850. Do uso do instrumento de posse, que hoje chamaríamos de grilagem, resultou que, ao se baixar a Lei de Terras, esta, ao contrário de reordenar a estrutura latifundiária, acabou por sancioná-la ao mesmo tempo que, a partir daí, impediu o acesso à terra a todos que não tivessem capital (Smith, 1990:304).

Francisco Iglésias, em seu livro sobre a Política Econômica do Governo Provincial, assinalou que as terras disponíveis em Minas Gerais, depois de 1850 , para efeitos do disposto na Lei de Terras, eram apenas $18 \%$ do total das terras da Província. Este dado, que talvez não possa ser generalizado, dá conta do quanto a "fronteira"já estava fechada em Minas Gerais, do quanto a terrajá estava monopolizada segundo as regras da velha ordem senhorial, bloqueadora do desenvolvimento de um efetivo mercado de terras capitalista, ou da implantação da pequena propriedade (Iglésias, 1958).

Talvez também em História, alguém chegue, algum dia, a dizer que traduzir é trair tal como comparar. Isto porque as comparações têm sempre algo de arbitrário, de incompatível como o específico da historiografia, que deve, sobretudo, zelar para interditar o anacronismo e as aproximações indevidas. 
É o risco que se corre quando se busca comparar realidades tão diferentes como as do Brasil e dos Estados Unidos. De todas as aparentes semelhanças só uma, de fato, resiste à análise criteriosa. De todas as pseudo-semelhanças só o avantajado do território é comum aos dois países. Se ambos viveram sob a condição colonial em algum momento, diferenças decisivas separaram suas respectivas trajetórias coloniais. No essencial, estas diferenças traduziram-se no seguinte: enquanto nos Estados Unidos o capitalismo - isto é, a competição, a acumulação, a maximização do lucro, a busca do aumento da produtividade do trabalho - foi o próprio móvel da colonização; no Brasil, toda a maquinaria econômica instalada aqui, a empresa comercial que predominou, tinha como destinação a reiteração de privilégios e interesses arcaizantes, a promoção da riqueza como apanágio do senhorio tradicional apegado, no essencial, aos valores e hegemonia do Antigo Regime. É assim que se explica porque a Independência do Brasil não tenha significado qualquer transformação estrutural, que a escravidão, o latifúndio, a hegemonia dos "homens bons", tenham se mantido, do mesmo modo que se mantiveram o caráter subordinado da economia, a estreiteza do mercado interno.

Faça-se assim a comparação, não como exercício arbitrário, mas como inventário das diferenças, como explicitação dos modos e contingências do processo de constituição do capitalismo, da constituição do mercado interno nos dois países. O que está implícito na comparação que se vai fazer não é uma perspectiva que abstraia as singularidades, as diferenças, que são a própria matéria da realidade histórica. Não há aqui qualquer "idealização" do capitalismo - pois este, sendo um processo histórico, é, sobretudo, irrepetível. O que está implícito aqui é que a gênese do capitalismo, em cada espaço geográfico específico, é sempre tributária do conjunto das realidades sócio-político-econômico-culturais-naturais nas quais emerge. Ou seja, ela é sempre marcada pela correlação de forças dominantes, resultando daí sua especificidade.

A grande dificuldade aqui, como em todo processo dialético, é reconhecer a tensão-movimento que se coloca na tríade generalidade $\longrightarrow$ particularidade $\longrightarrow$ singularidade, a qual no caso aqui se manifesta da seguinte forma: o capitalismo, modo de produção genérico tem supostos universais-genéricos (o dinheiro, os preços, as mercadorias, o mercado, a força-de-trabalho, o capital...). Contudo, estes supostos universais são permanentemente alterados pela própria dinâmica capitalista, que produz desigualdades - concentração, centralização do capital — e que são particularidades do capitalismo; finalmente estas particularidades são 
submetidas ao escrutínio de formas geo-históricas concretas, realidades singulares e contingentes, que determinam a presencialidade do capitalismo, que se dá sempre como realidade singular, específica, "nacional-local-regional".

Portanto, não se trata aqui de estabelecer hierarquias, de ver nos Estados Unidos um modelo ou caminho necessário, mas apenas reconhecer que o capitalismo é um processo histórico - o que significa dizer que cada realidade nacional terá o seu próprio caminho para o capitalismo, estando implícito, por suposto, que nem todos os caminhos serão exitosos, ou produzirão os mesmos resultados.

Iniciemos a comparação pela Lei de Terras no Brasil com a similar norte-americana, o Homestead Act de 1862, que sobretudo buscará, de fato, distribuir terras, determinando a constituição de uma estrutura fundiária baseada na pequena propriedade e no trabalho familiar, absorvendo por este processo milhões de imigrantes os quais, na corrida para o oeste, determinarão tanto a ocupação efetiva do território, quanto a ampliação do mercado interno, base para a urbanização e a industrialização americanas (Costa, s.d.:150-157).

As diferenças entre as filosofias que presidiram a Lei de Terras no Brasil e o Homestead Act, nos EUA, refletem, no fundamental, o lugar dos interesses especificamente capitalistas no interior do aparelho do Estado, e no conjunto da sociedade dos dois países. Isto é, enquanto no Brasil o Estado e a sociedade ainda estavam submetidos a um senhorio escravista, mercantilista e exportador, cópia "nacional" dos velhos interesses colonialistas, nos Estados Unidos, os interesses do grande capital já eram hegemônicos, o que seria definitivamente demonstrado pela vitória do Norte na Guerra Civil de 1861-65.

Em texto recente, Lígia Osório Silva discutiu as teses de Tavares Bastos para uma política de terras do Império brasileiro, inspirada na experiência norte-americana. Sua conclusão é reveladora:

"Tavares Bastos tinha, portanto, razão em citar o exemplo norteamericano, porque não obstante a política de terras ter favorecido mais os especuladores e os grandes capitalistas do que os pequenos fazendeiros independentes, ainda assim permitiu a formação da pequena propriedade numa escala incomparável." (Silva, 1998:28).

Antecipando uma conclusão mais geral, é possível ver nas diferenças entre as leis de terras do Brasil e dos Estados Unidos a ossatura básica da constituição dos mercados internos destes dois países - isto é, a di- 
ferença entre um mercado interno amplo e consistente, que é o caso norte-americano, e um mercado interno restrito e excludente, realidade permanente do Brasil. Resultam daí tanto diferenças no referente a constituição da nação - isto é, no grau de integração social e na capacidade do Estado de garantir direitos sociais básicos, e deste modo algum grau de coesão nacional - como diferenças em relação ao tônus dos capitalismos que vão se implantar nos dois países. Dito de outro modo, o tamanho e a consistência do mercado interno está diretamente relacionado à capacidade de coesão nacional e ao desenvolvimento da vida econômica de ambos.

Tanto no Brasil quanto nos Estados Unidos, a questão da terra foi objeto de tensões e disputas. Lá os interesses dos grandes proprietários de terra do Sul expressaram-se na defesa de uma política de terras que consagrasse tanto o latifúndio como o trabalho escravo. A lei de terras norte-americana de 1862 , e a abolição da escravidão, em 1863 , no contexto da Guerra Civil, são sinais inequívocos da vitória dos interesses especificamente capitalistas. No Brasil, ao contrário, esses interesses especificamente capitalistas demorarão muito para se impor, e mesmo quando o fizeram não foi sem ambigüidades.

Entre as teses de José Bonifácio, sobre a necessidade de se suprimir a distribuição sesmarial de terras, a necessidade do fim do tráfico e da escravidão, por volta de 1821-1823, e a efetiva mudança da política de terras e o fim do tráfico, passaram-se 29 anos. Dessa data, 1850, até a Abolição em 1888, mais 38 anos. Além desta dilação, desta procrastinação lembre-se do caráter limitado desta medida,já que ela não significou a plena emancipação dos escravos na medida em que isto implicaria, desde logo, uma reforma agrária que garantisse ao ex-escravo direitos sociais básicos - terra, trabalho, educação, saúde - como, por exemplo, advogava André Rebouças.

Trata-se, portanto, de reconhecer que, se o processo de constituição do mercado interno no Brasil atendeu aos interesses do senhorio mercantil-exportador e escravista nacional, este mesmo senhorio apresentava-se, no plano mais geral das relações econômicas internacionais, como sócio menor e subordinado ao grande capital internacional. Esta permanência da dominação colonial traria conseqüências de toda ordem para o desenvolvimento econômico, político social e cultural do País. No que interessa mais imediatamente a esta discussão sobre a constituição do mercado interno no Brasil, é preciso registrar que a continuidade, no essencial, do caráter colonial da economia brasileira no século XIX, significou manter o País basicamente como empresa exportadora, com 
baixo nível de autonomia, uma pequena capacidade de introjeção de progresso tecnológico, sujeita, por causa disso, às oscilações do mercado internacional. Comprova-se isto lembrando a relativamente curta carreira de sucesso da borracha, as freqüentes vicissitudes do mercado internacional do café por ocasião da Guerra Civil norte-americana em 1861 65, e da grande depressão econômica internacional a partir de 1873 etc.

Um ponto central a lembrar aqui é que, se a Lei de Terras de 1850 e a Lei Eusébio de Queiroz também, de 1850 , foram instrumentos solidários e complementares na transição para a constituição do mercado de trabalho e de terras no Brasil, elas foram sobretudo instrumentos da reafirmação de um senhorio marcado pela experiência colonial, apegado a um projeto de dominação arcaico, em que a produção da riqueza, a economia, reproduzem as velhas aspirações de status e poder de uma elite prisioneira de uma modernidade pelas metades (Fragoso e Florentino, 1996).

Neste sentido, os elementos básicos da Lei de Terras, antes de atenderem aos interesses de uma burguesia moderna, atendiam, naquele momento e até um bom pedaço do século XX, aos interesses de um senhorio herdeiro dos paradigmas dos potentados coloniais, incapaz de abraçar um projeto de desenvolvimento autônomo da economia o que implicaria, como se vê em todos os casos de economias fortes - EUA, Japão, França, Inglaterra, etc. - em processos conseqüentes de distribuição de renda e da riqueza, em distribuição primária da renda como assinalam Amartya Sen e Celso Furtado.

Assim, a forma particular como se deu a constituição do mercado de terras no Brasil, parte de nossa singular acumulação primitiva, significou, na prática, o adiamento de uma efetiva transformação capitalista do campo.

\section{O Mercado de Trabalho}

Foi também como um processo marcado por ambigüidades e tensões que se deu, no Brasil, a constituição do mercado de trabalho, na longa e complexa transição do trabalho escravo ao trabalho livre e deste ao trabalho assalariado, a qual tomou todo o século XIX e parte significativa do século $X X$, e cujo sentido geral refletiu, nas suas vicissitudes e especificidades, o modo atrofiado da acumulação primitiva de capital no Brasil. Em outro texto chamou-se a atenção para uma espécie de "saudades de acumulação primitiva de capital" (Paula, 1983), que teria 
marcado o discurso das elites empresariais em Minas Gerais desde Eschwege, que esteve no Brasil entre 1811 e 1821 , até o Congresso Agrícola, Comercial e Industrial de Minas Gerais, de 1903. Mas não foram somente as elites mineiras que vocalizaram esta "saudade", a necessidade de complementação do processo de proletarização da força de trabalho. Estudando o discurso das elites agrícolas das Províncias de Minas Gerais, Espírito Santo, Rio de Janeiro e São Paulo, em 1878, Peter Eisenberg detectou a mesma queixa-reivindicação. Como diz ele:

"A questão da mão-de-obra foi uma das questões mais discutidas nas últimas décadas do Império" (...) "Em 1878 essa questão voltou a ser discutida com uma certa insistência em dois congressos agrícolas realizados no Rio de Janeiro, e em Recife". (...) "A primeira pergunta colocada pelo ministro da Agricultura indagava sobre as necessidades mais urgentes e imediatas da grande lavoura. A grande maioria das pessoas que respondeu à pergunta apontou para falta de braços:"(...) "Os entusiastas do trabalhador livre nacional afirmaram que este vivia na ociosidade, estando desempregado ou subempregado" (...) "A concordância a respeito da ociosidade do trabalhador livre nacional não impediu que os congressistas discordassem quanto as causas e curas desse inatividade. As causas foram encaradas como falta de repressão, politicagem e ausência de incentivos positivos. Quem identificava a ociosidade como resultado da falta de repressão apelou para a correção e polícia que moralize e sujeite ao trabalho a classe jornaleira" (Eisenberg, 1989:140,142,143,144 e 145).

Não é possível deixar de reconhecer aí as mesmas motivações que levaram à "legislação sanguinária" de que fala Marx ao estudar a acumulação primitiva; às Workhouses e outras formas de disciplinamento da classe operária em constituição.

Por outro lado, se se analisar o discurso das elites agrárias nordestinas, reunidas em Recife, neste mesmo 1878, o panorama é outro.Tangidos pela seca de 1877, milhares de nordestinos (a historiografia oscila entre 200 e $500 \mathrm{mil}$ ), inteiramente expropriados, permitiram às elites nordestinas responderem negativamente à pergunta sobre a falta de braços. De acordo com Eisenberg, "quem negava a falta de braços no Nordeste 0 fez em vista da conjuntura de 1878 , quando milhares de sertanejos flagelados pela grande seca de 1877-79 invadiram a Zona da Mata e aparentavam uma grande reserva de mão-de-obra" (Eisenberg, 1989:170). 
Entre as elites sulinas, em 1878 , era consensual a tese da necessidade da imigração de estrangeiros (Eisenberg, 1989:150). Na verdade, esta questão, encaminhada desde 1847 através das iniciativas do Senador Vergueiro, formajunto com a Lei de Terras de 1850 , e com a lei do fim do tráfico, também de 1850 , a tríade básica da constituição do mercado de trabalho livre no Brasil. A esta tríade básica devem ser associadas ainda a Lei doVentre Livre, de 1871, a Lei de Locação de Serviços, de 1879 e a Lei dos Sexagenários, de 1885, os diplomas legais que explicitaram, no planojurídico-institucional, os resultados das importantes transformações que foram se dando no plano político-econômico-social, e cujo desenlace foi a Abolição, em 1888.

Em Mercado de Trabalho Livre no Brasil (1871-1888), Ademir Gebara traçou um quadro da constituição do mercado de trabalho no Brasil, dando destaque tanto à lei de 1871 quanto de 1879, que representariam intervenções do Estado para garantir a transição ordenada e o controle sobre o mercado de trabalho no Brasil.

Trata-se aqui de entender como a longa trajetória da abolição no Brasil - das teses de José Bonifácio, em 1821, até 1888 - condensa no conjunto de suas determinações e vicissitudes, as tensões, os limites e as contradições da constituição do capitalismo no Brasil. Para isso, cabe iniciar a análise pela Lei do Ventre Livre, de 1871, também chamada de Lei Rio Branco. Em 1871, oVisconde do Rio Branco foi convidado para chefiar Gabinete que teria como missão viabilizar quatro grandes reformas - a do sistema eleitoral; a da administração da justiça; a da Guarda Nacional e a do elemento servil (Gebara, 1986:29).

Esta última reforma materializou-se na Lei de Ventre Livre, que tinha os seguintes aspectos básicos: 1) todos os filhos de escravos nascidos a partir de 28/9/1821 seriam livres; 2) seria constituído um Fundo para Emancipação de Escravos; 3 ) foram criadas sociedades emancipatórias - e mandou-se libertar os escravos pertencentes a escravos e 4) em dispositivo bastante sintomático das motivações da Lei, lia-se que "em geral, os escravos libertados em virtude desta lei ficam durante cinco anos sob a inspeção do governo. Eles são obrigados a contratar seus serviços sob pena de serem constrangidos, se viverem vadios, a trabalhar em estabelecimentos públicos. Cessará, porém, o constrangimento do trabalho sempre que o liberto exibir contrato de serviço" (Gebara, 1986:51-52).

A Lei do Ventre Livre, por seus dispositivos e motivações, resultou de uma perspectiva que, por várias razões, foi se impondo às elites brasileiras, as quais tiveram que admitir o fim do trabalho escravo, mas 
que pretenderam controlar este processo para que fosse ordenado, gradual e, sobretudo, sem prejuízos para os proprietários de escravos...

Muito se tem discutido sobre as determinações essenciais do processo de Abolição. No texto de Gebara há uma síntese compreensiva que relaciona tanto a pressão inglesa, quanto o resultado das contradições abertas pela participação dos escravos na Guerra do Paraguai, e a escalada de movimentos de resistência e rebeldia dos escravos a partir de 1860 (Gebara, 1986:49).

A Lei do Ventre Livre, como notaram vários estudiosos, foi, na verdade, uma eficaz tentativa de estabelecer um processo controlado de transição para o trabalho livre, com um único inconveniente, apontado por Rui Barbosa, que era sua absoluta lentidão. Esta levaria a que, no ritmo como estava se dando o processo, no século XX, o Brasil ainda teria cerca de 400 mil escravos (Gebara, 1986:70-72). Neste sentido, podese dizer que o que levou à Abolição sem indenização e à efetiva ruptura representada pela Lei de 1888 , foi, paradoxalmente, a excessiva eficácia da Lei de 1871.

Se a Lei de 1871 constituiria uma sinalização clara da marcha da introdução do trabalho livre no Brasil, num processo sem sobressaltos, administrado pelo Estado, um outro componente deste processo, a imigração, continuou relativamente atrofiado até 1879. Foi só com a Lei de Locação de Serviços, de 1879, que houve uma regulamentação das garantias dadas a trabalhadorimigrante. Segundo Gebara,"o objetivo da lei de 1897 foi tornar as condições de vida mais atrativas para o imigrante, de tal maneira que fossem oferecidas a eles alguma garantia e proteção legal" (Gebara, 1986:88).

A legislação sobre o trabalho no Brasil teve seu primeiro instrumento numa lei de 1830, regulando o trabalho dos nacionais. Em 1837, a lei $n^{\circ} 108$, de 11 de outubro regulou o trabalho dos estrangeiros.

A Lei de 1879 teve três objetivos básicos: a) a locação de serviços propriamente ditos; b) a parceria agrícola e c) a parceria pecuária. No essencial, esta lei vinha complementar a regulamentação das relações do trabalho no Brasil. Veja-se a seqüência deste processo em Gebara: "escravos e libertos, pela Lei do Ventre Livre; trabalhadores agrícolas brasileiros e imigrantes, pela Lei de Locação de Serviços de 1879; trabalhadores não-empregados em serviços agrícolas,pelo Código Comercial e, parcialmente, pelas ordenações, como previamente ocorria" (Gebara, 1986:90).

Todos os que discutiram a Lei de 1879 apontaram que sua motivação essencial foi a de desbloquear a pesada camada de suspeitas que, sobretudo 
na Europa, pesava sobre as condições dos trabalhadores imigrantes no Brasil. As tensões e revoltas como as relatadas por Thomas Davatz em seu livro Memórias de um Colono no Brasil (1850), dando conta das tentativas de escravização dos imigrantes precisavam ser afastadas para que o Brasil, efetivamente, pudesse continuar a recebê-los. A lei de 1879 dava essa garantia.

Contudo, foi só com a efetiva entrada do Estado no processo, mediante o financiamento do transporte e da instalação dos imigrantes, que a imigração alcançou o caráter maciço que teve entre 1885 e 1914.

Todas as mudanças apontadas aqui - a modernização das relações de trabalho, a mercantilização da terra - têm mais de uma determinação. De qualquer forma não será reducionismo afirmar que o núcleo principal destas mudanças foi a economia cafeeira. A idéia básica é a de que o café em sua expansão foi enfrentando certos obstáculos cuja remoção implicou em transformações estruturais da vida econômica e social no Brasil.

O primeiro obstáculo que se colocou para a expansão cafeeira foi o relativo à mão-de-obra. Pressionado pela Inglaterra, afetado pelas conseqüências da Guerra do Paraguai, desafiado pela aceleração da resistência dos escravos, o Império iria responder primeiro em $1850 \mathrm{com}$ o fim do tráfico, ao mesmo tempo em que resolveu "fechar a fronteira"- isto é, impedir o acesso à terra, baixando a Lei de Terras. Estas duas medidas legais foram os pontos de partida da constituição dos mercados de trabalho e de terras. Ao lado da abolição gradual da escravatura, o mercado de trabalho no Brasil seria decisivamente incrementado pela política de imigração — seja por meio da Lei de Locação de Serviços de 1879, seja pelas leis provinciais de São Paulo. Veja-se a respeito o que diz Emília Viotti da Costa:

"Entre 1884 e 1888, várias leis foram aprovadas pela Assembléia Legislativa destinadas a favorecer a imigração: Lei Provincial de 29 de março de1884,1ei de 11 de fevereiro de 1885 , de 21 de março de 1885 , de 28 de maio de 1886, de 11 de abril de 1887" (Costa, 1989:219).

Um outro obstáculo que iria colocar-se para a expansão cafeeira foi a terra. Havia aqui duas questões imbricadas. A primeira se referia ao esgotamento das terras da geografia tradicional do café: da Corte ao Vale do Paraíba Fluminense e Paulista, e daí à Zona da Mata de Minas Gerais. O esgotamento destas terras levou à ocupação das terras do chamado "OesteVelho" de São Paulo, cujo centro foi a cidade de Campinas, e mais tarde as terras do "Oeste Novo", cuja centralidade seria 
dada por Ribeirão Preto. Nessa caminhada para Oeste a produtividade física dos cafezais mais do que dobrou. Um outro ponto a destacar aqui é que a lucratividade da atividade cafeeira e sua rápida expansão determinaram, efetivamente, a complementação do "fechamento da fronteira", com a terra passando a ser monopolizada pelos grandes proprietários.

O terceiro obstáculo enfrentado pela expansão cafeeira residia no sistema de transportes. A resposta a este obstáculo, o desenvolvimento das ferrovias, barateou os custos de transportes e ampliou a capacidade de carga, permitindo uma efetiva integração entre as áreas produtoras e os portos, e, afinal, criando condições para a unificação do mercado interno. De resto, a expansão ferroviária também teve repercussões importantes sobre o desenvolvimento da mecanização no Brasil (Silva, $1976)$.

\section{Limites da Constituição do Mercado Interno no Brasil}

Desde a Independência, é possível rastrear várias iniciativas do Estado no sentido de instaurar no Brasil relações mercantis em substituição às velhas instituições do Antigo Regime. Senão vejamos: 1) em 1824, na Constituição, são abolidas as corporações de ofício; 2) em 1835 é abolido o instituto do morgadio; 3) em 1850 é proibido do tráfico de escravos; 4) também em 1850 é baixada Lei deTerras; 5) no mesmo ano de 1850 , aprova-se o Código Comercial; 6) data de 1864 a regulamentação das hipotecas fundiárias (Smith, 1990:377). Se a esta lista de Roberto Smith se adicionar a legislação sobre a Abolição — de 1871,1885 e 1888 bem como a relativa à imigração e à locação de serviços, ter-se-á um quadro em que transparece o papel do Estado como agente de modernização institucional, sempre refletindo, é claro, interesses e motivações de setores do senhorio brasileiro.

Neste sentido, apesar do atraso com que algumas medidas foram tomadas, apesar da procrastinação e da timidez de certas atitudes, devese concluir pela existência de um projeto modernizante no Brasil imperial. Contudo, e é esta a questão central, tais iniciativas e mudanças foram de tal ordem e foram marcadas por tais limitações, que o resultado final seria a instauração de uma modernidade atrofiada, a constituição de um mercado incompleto e excludente, a afirmação de privilégios e desequilíbrios, e a reiteração de desigualdades sociais e regionais comprometedoras tanto da construção nacional quanto da democracia.

Estes aspectos problemáticos da modernização brasileira tanto podem 
ser percebidos no plano interno, pela análise da heterogeneidade regional do processo de constituição do mercado interno no Brasil, como podem ser inferidos através da comparação destes processos com os experimentados por outros países. Uma comparação a que não se resiste é a com os Estados Unidos. Comparação que será tanto mais legítima quanto mais as diferenças das trajetórias dos dois países sejam consideradas em termos rigorosamente históricos, para além dos preconceitos que costumam cercar estas questões.

Neste esforço comparativo serão considerados os seguintes aspectos como índices do desenvolvimento do mercado interno: 1) a população; 2) as imigrações; 3) a malha ferroviária; 4) os trabalhadores no setor industrial; e 5) o número de unidades industriais.

No que se refere à população o quadro é o seguinte:

Tabela 1. População do Brasil e dos Estados Unidos (1800-1930) em milhões de pessoas

\begin{tabular}{lcc}
\hline Anos & BRASIL & ESTADOS UNIDOS \\
\hline 1800 & 3,33 & 3,93 \\
1850 & 7,23 & 23,19 \\
1870 & 9,80 & 39,82 \\
1890 & 14,20 & 62,95 \\
1900 & 17,98 & 75,99 \\
1920 & 27,40 & 105,71 \\
1930 & 33,57 & 122,78 \\
\hline
\end{tabular}

Fonte: Merrick e Graham, 1980:47.

A expressiva defasagem que foi se estabelecendo entre o crescimento populacional dos dois países ao longo do século XIX deveu-se, sobretudo, à imigração.Veja-se a respeito o quadro que segue:

Tabela 2. Imigração para o Brasil e os Estados Unidos (1860-1920) — número de pessoas

\begin{tabular}{crc}
\hline \multicolumn{1}{c}{ Anos } & BRASIL & ESTADOS UNIDOS \\
\hline $1860-1869$ & 110.093 & 2.000 .000 \\
$1870-1879$ & 193.931 & 3.000 .000 \\
$1880-1889$ & 527.869 & 5.000 .000 \\
$1890-1899$ & 1.205 .803 & 4.000 .000 \\
$1900-1909$ & 649.898 & 9.000 .000 \\
$1910-1919$ & 821.458 & 6.000 .000 \\
\hline
\end{tabular}

Fontes: Ianni, 1963:99; Cole, 1966:98. 
Um aspecto decisivo, apontado por todos os que se dedicaram a estudar a constituição do mercado interno capitalista, é o referente ao desenvolvimento do sistema de comunicações e transportes. Neste sentido teria uma importância decisiva, tanto para o caso pioneiro inglês, quanto para outras economias, a expansão das ferrovias. Vários autores sublinharam o papel estruturante e formativo das ferrovias em pelo menos três aspectos: como mecanismo de unificação do mercado interno; como instrumento de barateamento dos custos de transporte; e como instrumento indutor de desenvolvimento tanto da indústria de bens de capital quanto da formação da mão-de-obra industrial. Tratase pois de ver na expansão ferroviária um índice de consistência e força do mercado interno. Como disse Edward C. Kirkland referindo-se aos Estados Unidos:

"As ferrovias agregadas às possibilidades do Homestead Act, colonizaram o Oeste com a rapidez do fogo nas pradarias; e, ao mesmo tempo que no Oeste tinham lugar estas mudanças, as ferrovias facilitariam a concentração de indústrias no Leste dos Estados Unidos" (Kirkland, 1947:363).

Eis os dados comparativos entre a expansão ferroviária do Brasil e dos Estados Unidos:

Tabela 3. Expansão das Ferrovias no Brasil e nos Estados Unidos (1860-1920) em quilômetros

\begin{tabular}{ccc}
\hline Anos & BRASIL & ESTADOS UNIDOS \\
\hline 1860 & 216 & 49.008 \\
1870 & 808 & 85.440 \\
1880 & 3.488 & $135.028,8$ \\
1890 & $16.225,6$ & $258.235,2$ \\
1900 & - & $310.819,2$ \\
1910 & $27.148,8$ & $387.371,2$ \\
1920 & $38.820,8$ & $405.043,2$ \\
\hline
\end{tabular}

Fonte: COLE, 1966, Anexo.

Os trabalhadores industriais nos Estados Unidos eram 957.059 em 1849, passando a 2.053.996 em 1869 (Costa, s.d.:157-158). Para o Brasil os números foram os seguintes: 54.169 trabalhadores industriais em 1889; 149.018 em 1907, e 275.512 em 1920 (Silva, 1976:78). No que se refere ao número de empresas industriais os Estados Unidos tinham, em 1848, 123.025, e passaram a ter 353.863 em 1868 (Costa, s.d., loc. cit.). A marcha da instalação de empresas industriais no Brasil 
foi a seguinte: em 1870 existiam 636, em 1907 este número passou a 3.258, chegando a 13.336 em 1920 (Silva, 1976:78).

São números que impressionam, sobretudo, quando se considera que a população dos países era semelhante no início do século XIX, e que os dois também se assemelham do ponto de vista do tamanho do território. Estas gritantes disparidades não são resultados de qualquer fatalidade natural, de qualquer condenação climática ou racial. Elas são os resultados de duas trajetórias distintas de recepção-construção do capitalismo. Desde logo, um ponto central a se destacar é que a vigorosa expansão capitalista norte-americana deveu-se à sua singularíssima experiência colonial. Isto é, os Estados Unidos, de fato, nunca foram colônia, no sentido e com as implicações que isto teve para o Brasil (Paula, 1992). Esta peculiaridade permitiu que os Estados Unidos pudessem sair da condição colonial, em 1776, detentores de considerável base de acumulação interna, tendo sido esta a principal alavanca do seu desenvolvimento capitalista. Ou seja, os Estados Unidos conseguiram, já durante o período colonial, realizar um dos dois processos essenciais da acumulação primitiva - a acumulação de capital-dinheiro, de riqueza monetária e financeira - que seria a base da sua grande expansão na segunda metade do século XIX e no início do XX.

Trata-se, então, de reconhecer que há uma diferença essencial entre o Brasil e os Estados Unidos, que explica grande parte das distintas trajetórias capitalistas destes países e que foi a forma como viveram a condição colonial. A esta determinação básica acrescente-se um desdobramento disto que foi a forma como os dois países desenvolveram seus processos de acumulação primitiva - seja em termos de velocidade, seja em termos de extensão e profundidade, seja, sobretudo, no relativo ao grau de autonomia destes processos.

O essencial das diferenças entre os dois países, neste sentido, está no fato de que tanto o processo de constituição do mercado interno no Brasil, quanto o de realização mais geral da acumulação primitiva, foram marcados por atrofiamento, incompletamento, heterogeneidade e dependência externa, e, sobretudo, por uma tal destinação, que acabou por reiterar velhos privilégios oligárquicos antes de generalizar e impessoalizar as relações capitalistas.

Por outro lado, uma outra grande diferença entre os processos de instauração capitalista nos dois países foi a circunscrição do processo no Brasil, durante tempo considerável, à Província depois Estado de São Paulo. Dito de outra forma: desde o final do século XIX e até os anos 1950, se não até data posterior, a industrialização capitalista, a 
generalização do mercado capitalista no Brasil restringiu-se praticamente a São Paulo, como resultado da sua dinâmica cafeeira e das transformações que ela engendrou e multiplicou.

Neste sentido, a comparação entre a expansão cafeeira paulista e a que ocorreu em Minas Gerais no mesmo período pode lançar alguma luz sobre aspectos importantes da questão. Trata-se aqui de atentar para uma diferença decisiva que singularizou o caso de São Paulo. Esta diferença foi a extraordinária expansão cafeeira de São Paulo em sua marcha para o oeste, vis-à-vis à crescente estagnação tanto da cafeicultura fluminense, quanto da mineira e a do Vale do Paraíba paulista. As cidades mortas, de que fala Monteiro Lobato, são o outro lado de uma moeda que tem uma outra face brilhante, expansiva de prosperidade e otimismo, nas cidades que nasceram e se enriqueceram com o café. Como diz Sérgio Milliet:

"O avanço se processou na obediência a duas determinantes principais: evitar a linha do Trópico, abaixo da qual o clima não favorecia, e demandar as grandes florestas de terravirgem e milionária. O oeste é o ponto cardeal do agricultor, o horizonte para o qual ele se dirige, e que recua sempre e sempre, até perder-se no norte do Paraná, onde desde alguns anos, se vêm implantando as primeiras fazendas ainda tributárias das estradas de ferro paulistas."

"Atrás do café, e por vezes à sua frente, penetram as ferrovias. Com elas os colonos estrangeiros e o comércio semi-sedentário. Cidades erguem-se, crescem rápidas, sem tempo suficiente para tomar pé, sem raízes bastante fortes para resistir desde logo às vicissitudes da marcha vertiginosa e fatigante" (Milliet, 1982:19-24).

Trata-se de um avanço vertiginoso como foi dito, avanço esse que significou: 1) a criação de condições para o efetivo fechamento da fronteira, nosso "cercamento das terras", com o surgimento da renda da terra e o encarecimento de seus preços; 2) a aceleração da entrada de imigrantes, neste sentido a efetiva constituição do mercado de trabalho livre em São Paulo; 3) e, finalmente, a expansão ferroviária que foi instrumento da plena unificação do mercado interno paulista.

Se compararmos este quadro com o prevalecente em outras regiões do País, o contraste é expressivo. Uma primeira comparação com Minas Gerais mostra que, até 1880 , a produção cafeeira de São Paulo assemelhava-se à de Minas Gerais e Rio de Janeiro. Foi a partir daí que ocorreu o grande salto, e este corresponde à definitiva chegada do café ao Oeste Novo. 
No que se refere a Minas Gerais, o século XIX, como também já ocorrera no século XVIII, foi marcado pela diversificação produtiva, dispersão espacial, e pulverização dos empreendimentos. Em que pese a existência de importantes diferenças de ênfase e de pontos de vista, a moderna historiografia econômica sobre Minas Gerais no século XIX talvez reconheça, no geral, que o traço efetivamente marcante da economia mineira, naquele período, traduziu-se, ao lado de seu dinamismo, silencioso ou não, dependente da nova mineração ou não, resultante ou não da expansão cafeeira, na ausência de um efetivo processo de proletarização e de constituição de um mercado capitalista de terras. A idéia básica aqui é que o dinamismo que efetivamente ocorreu em Minas Gerais no século XIX deu-se no contexto de uma reiteração tanto das velhas relações de trabalho e escravidão, quanto da manutenção da velha estrutura de posse de terras.

Neste sentido, a grande diferenciação entre Minas Gerais e São Paulo iria dar-se pós-1880, pela aceleração da acumulação primitiva que ocorreu em São Paulo, enquanto que em Minas Gerais, até a década de 1950, mesmo em regiões com considerável grau de modernidade, prevaleceriam traços de um processo de proletarização incompleta (Paula, $1983)$.

Num volume coletivo, Frédéric Mauro, La Préindustrialisation du Brésil, (1984), organizou um panorama geral dos processos de industrializações regionais no Brasil, que não resultaram, no século XIX e na primeira metade do século XX, numa consolidação da grande indústria capitalista, como em São Paulo. O esforço meritório desses trabalhos foi o de sublinhar que o caso de São Paulo não é um caminho a ser seguido, mas o resultado de um processo histórico concreto irrepetível.

Deste fato decorrem várias questões a se considerar: 1) que a atual hegemonia industrial e econômica de São Paulo foi resultante do pioneirismo paulista em completar a acumulação primitiva de capital em seus aspectos essenciais; 2) que, neste sentido, e numa compreensão global do desenvolvimento do capitalismo no Brasil, tem que se buscar estabelecer o conjunto das circunstancias que condicionaram, em cada caso, cada processo regional de acumulação primitiva de capital; 3 ) que, assim, constitui reducionismo injustificável resumir a história econômica do Brasil, no século XIX, à trajetória da economia cafeeira em São Paulo; 4) que, em qualquer caso, o desenvolvimento do capitalismo no Brasil foi e é profundamente condicionado pelo conjunto das formas de inserção da economia brasileira no capitalismo internacional; e 5) finalmente, ressaltar que o desenvolvimento autônomo da economia 
brasileira, sua capacidade de contemplar a melhoria de qualidade de vida do conjunto da população depende do grau de generalização da distribuição primária da renda, tal como foi postulado por Celso Furtado em A Construção Interrompida (1992).

\section{Bibliografia}

Braudel, Fernand. Civilização Material, Economia e Capitalismo. Trad. porc.Tomo II. Lisboa: Cosmos, 1985.

Cardoso, Ciro F. S. Agricultura, Escravidão e Capitalismo. $2^{a}$ edição. Petrópolis:Vozes, 1982, cap. IV.

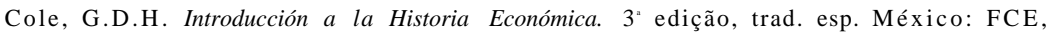
1966.

Costa, Emília Viotti da. Da Monarquia à República. 5 edição. São Paulo: Brasiliense, s.d. Da Senzala à Colônia, $3^{\mathrm{a}}$ edição. São Paulo: Brasiliense, 1989.

Eisenberg, Peter L. Homens Esquecidos. Campinas: EDUNICAMP, 1989.

Fragoso, João e Florentino, Manolo. O Arcaísmo como Projeto. $2^{a}$ edição. Rio de Janeiro: Sette Letras, 1996.

Furtado, Celso. Brasil. A Construção Interrompida. Rio de Janeiro: Paz e Terra, 1992.

Gebara, Ademir. O Mercado de Trabalho Livre no Brasil (1871-1888). São Paulo:Brasiliense, 1986.

Huizinga, Johan. El concepto de la Historia. Trad. esp. 8 edição. México: FCE, 1980.

Ianni, Octavio. Industrialização c Desenvolvimento Social no Brasil. Rio de Janeiro: Civilização Brasileira, 1963.

Iglésias, Francisco. Política Econômica do Governo Provincial Mineiro (1835-1889). Rio de Janeiro: INL, 1958.

Introdução à Historiografia Econômica. Belo Horizonte: FCE/UMG, 1959.

Kirkland, Edward C. Historia Económica de Estados Unidos. $2^{a}$ edição, trad. esp. México: FCE, 1947.

Lênin,V. I. El Desarrollo del Capitalismo en Rusia. $3^{\text {a }}$ edição, trad. esp. Buenos Aires: Estudio, 1973.

Marx, Karl. O Capital. Livro I, trad. port. Rio de Janeiro: Civilização Brasileira, 1968.

Mauro, Frédéric. (org.). La Préindustrialization du Brésil. Paris: CNRS, 1984.

Melo, Evaldo Cabral de. O Norte Agrário e o Império. Rio de Janeiro: Nova Fronteira/ INL, 1984.

Merrick, Thomas e Graham, Douglas. "População e Desenvolvimento no Brasil: uma perspectiva histórica" in Neuhaus, Paulo (org.). Economia Brasileira: uma visão histórica. Rio de Janeiro: Campus, 1980.

Milliet, Sérgio. Roteiro do Café e Outros Ensaios. 4" edição. São Paulo: HUCITEC/INL, 1982.

Neale, Walter C. "El mercado en la teoria y la historia", in Polanyi, Karl e outros. Comércio y Mercado en los Imperios Antiguos, trad. esp. Barcelona: Labor, 1976.

Paula, João Antônio de. "Dois Ensaios sobre a Gênese da Industrialização em Minas Gerais: a Siderurgia e a Indústria Têxtil", in II Seminário sobre a Economia Mineira. Belo Horizonte: UFMG, 1983.

. "Colombo e Tiradentes: Ensaios sobre a Colonização e a Descolonização",in VI Seminário sobre a Economia Mineira. Belo Horizonte: UFMG, 1992. 
Polányi, Karl."A nossa obsoleta mentalidade mercantil", in Revista Trimestral de Letras $e$ Idéias. Porto: Afrontamento, 1978.

Porto, Costa. Estudo sobre Sistema Sesmarial. Recife: Imprensa Universitária, 1965.

Schwartz, Stuart. Segredos Internos. Trad. port. São Paulo: Cia. das Letras, 1988.

Sereni, Emílio. Capitalismo y Mercado Nacional. Trad. esp. Barcelona: Crítica, 1980.

Silva, José Bonifácio de Andrada e. Escritos Políticos. São Paulo: Obelisco, 1964.

Silva, Ligia Osório."Tavares Bastos e a questão agrária no Império", in História Econômica e História de Empresas. São Paulo: HUCITEC/AB PHE, $2^{\circ}$ semestre, 1998.

Silva, Sérgio. Expansão Cafeeira e Origens da Indústria no Brasil. São Paulo: Alfa-Ômega, 1976.

Smith, Roberto. Propriedade da Terra e Transição. São Paulo: Brasiliense, 1990.

Wood,Ellen Meiksins. A Origem do Capitalismo. Trad.port.Rio de Janeiro:Jorge Zahar, 2001. 